\title{
Urban Experiments in Times of Crisis: From Cultural Production to Neighbourhood Commoning
}

\author{
Giorgos Chatzinakos \\ 'Everything will be as it is now, just a little different' \\ Giorgio Agamben (1993:53)
}

\section{Introducing the Context}

This chapter describes the development of the Alexandrou Svolou Neigbourhood Initiative ${ }^{68}$ (ASNI), a bottom-up and self-organised activist group that was founded in 2013 in Thessaloniki. Broadly speaking, the projects organised by ASNI aim to connect people to place by fostering an imaginative and intersectional framework, namely the 'Neighbourhood. The latter is seen as a common representation of place that can address and promote the role of locality and peoples' ability to engage with urban commons. The research is influenced by the 'new politics of place' (Amin 2004), the revaluation of the role of culture in urban regeneration (Oakley 2015) and the right to the city (Harvey 2012). By interrogating contemporary theoretical debates around human geography,

${ }^{68}$ Official Facebook page: https://www.facebook.com/geitonia.svolou/. Last access 20 November 2019.

How to cite this book chapter:

Chatzinakos, G. 2020. Urban Experiments in Times of Crisis: From Cultural Production to Neighbourhood Commoning. In Lekakis, S. (ed.) Cultural Heritage in the Realm of the Commons: Conversations on the Case of Greece. Pp. 183-212. London: Ubiquity Press. DOI: https://doi.org/10.5334/bcj.k. License: CC-BY 
sociology, cultural analysis and event management, the broad scope of this project is driven by the emerging roles of cities at a global level in a continuous, globalised and interconnected 'world of cities'. Likewise, the research considers the various socio-cultural representations of the city as fundamental to understanding urban life. It has been argued that "cities have always constituted typical spaces of exchange, where conflicting and confusing perceptions and representations crisscrossed continually, spaces where memories have been negotiated and processed" (Spiridon 2013: 206). The metropolis itself can be seen as "the site of biopolitical production, because it is the space of the common, of people living together, sharing resources, communicating, exchanging goods and ideas" (Hardt \& Negri 2009: 250). In this light, urban space can be subjected to a broad range of geographies of experimentation (Kullman 2013).

The overall relevance of urban experimentation lies in the fact that in recent decades cities have been undergoing globally radical transformations. According to the United Nations' report on global urbanisation prospects (2014), $54 \%$ of the world's population now resides in urban areas. This proportion is expected to increase to $66 \%$ by 2050 . As the world's population is increasingly concentrated in urban settlements, new conditions and challenges emerge in a fast-changing context. A reasonable macro-sociological question that arises is how will this 'world of cities' would look in 30 years' time? In this direction, Barber (2013) believes that cities, and the administrations that run them, offer the best possible new patterns of global governance and can be viewed as a formidable alternative to the conventional nation-state paradigm. In this sense, cities and urban networks can play a key role in engaging with global challenges that manifest locally. On the contrary, some argue that often those responsible for strategising management scenarios for cities forget that they are constituted by real people with real needs, desires and motivations (Miles 2017), producing hegemonic exclusion policies, incapable of creating impactful solutions to overcome actual problems through applicable interventions and practices.

With this in mind, this research focusses on Thessaloniki, at the same time both an ordinary and an extraordinary city (Mazower 2004; Robinson 2006). Thessaloniki would seem to embody an ongoing struggle to redefine its image and rewrite its urban myth, by integrating culture within its broader strategic development and planning initiatives. On the local level, there is an ongoing discussion around the role of residents in the midst of a 'more-than-financial' crisis (Athanassiou et al. 2018), coupled with an outlook aimed at developing Thessaloniki into the 'Metropolitan city of the Balkans' (Labrianidis 2011; Frangopoulos et al. 2009). However, evidence suggests that there is a "particular dynamic of interests established by specific elite categories that are capable of intervening and claiming public funding for their benefit" (Thoidou \& Foutakis 2006: 40). Along similar lines as Miles (2017), Christodoulou (2015) emphasises that there is a significant and stable deviation between the projected aims/priorities and the implemented interventions made by the municipal 
authorities compared to the needs and desires of the local community itself. Those symptoms of colonisation by a dominant economic, cultural and political hegemony, highlight the fact that the city is constructed around the needs of a privileged audience that, in turn, tend to relentlessly reproduce idealised and commodified images of the city, until they become more real than the reality itself (see Goodwin 1997). In addition, in terms of urban management it appears that the city's administration is not able to take into consideration the socio-cultural plurality and place-based particularities of its urban neighbourhoods, contributing to a particularly problematic governance of the city and its broader metropolitan area (Chatzinakos 2016: 167). Within the context of the chapter, findings highlight some limitations experienced in practice when it comes to the broader management of the urban fabric of a Greek city.

In this respect, this research tries to go beyond traditional definitions of participation and governance, attempting to design a tentatively transformative approach, through which we can learn from different experiences and representations, directly derived from urban communities. According to Providência (2015: 218) such an approach "privileges personal readings of an urban site and conceives of the "townscape" in terms of the public perception of urban space. This, in turn, fosters a planning attitude that privileges the particular, the lived space and the sidewalk, and that fights any abstract general planning that does not focus on improving quality of life". This approach (1) focuses on an overarching view of individual needs and collective desires, (2) offers a new dimension of thinking and opportunities for experiential learning, through various practices of everyday appropriation and commoning, (3) promotes the design of more inclusive neighbourhoods, (4) addresses and/or prevents social problems, (5) contributes to a broader understanding regarding the impact of crisis on the quality of life of a city, (6) allows for a new perspective on the complexity of urban life and (7) opens up new political imaginaries, essential for the transformation of urban life. This experience so far has introduced new elements on the discussion around the role of bottom-up initiatives in the midst of a 'more-than-financial' crisis.

\section{A Brief Historical Overview}

The crisis has initiated major transformations, which have brought with them new socio-cultural realities and forms of living, political imaginaries and spatial configurations. It is argued that the legacy of the crisis has not only impacted on local economies, but by now has become an embodied subjectivity, a material and sensory experience in everyday encounters in public space. As a response to this gradual yet inter-temporal stagnation, a highly diverse group of locals, comprised of residents, shopkeepers, researchers, activists, artists, students and one journalist, who lived in close proximity, formed the Alexandrou Svolou 
Neigbourhood Initiative in December 2013. The initial aim of the Initiative could be summed up in the phrase 'let's become a neighbourhood again'. In that sense, the revival of the notion of the 'Neighbourhood' is seen as a response to the economic crisis, which creates constant insecurity and fear, followed by the alienating effects of contemporary neo-liberal politics.

ASNI was first conceived on Facebook and then moved gradually from cyberspace to urban space. This informal social structure gradually began to acquire permanent standards and a social dimension. From the very beginning the main challenge was to develop a diverse network of people that would engage in common activities; creating a nodal space for communication and knowledge exchange. Upon creation, in order to set an organisational and ethical framework that would allow the creation and co-formulation of shared meanings, ASNI published a founding declaration and thereafter disseminated it to various individuals and community groups. This declaration is comprised of 10 social values.

These are:

1. We reinforce social ties by promoting self-action.

2. We highlight the value of collegiality and we actively contribute to the creation of an everyday urban 'warmth'.

3. We rejuvenate local creativity and inventiveness.

4. We exercise our right to the city, through exemplary actions. We critically highlight, document, and refer to the appropriate public institutions, the problems and the needs of our Neighbourhood.

5. We preserve the collective memory of our Neighbourhood and we learn its history.

6. We show that important things can be done without funding.

7. We facilitate the development of solidarity through horizontal, selforganised social structures.

8. We undertake things we had expected the institutions would provide.

9. We develop mutual relationships; cultivating trust and intimacy between residents and shopkeepers.

10. We improve the quality of life of our City and Neighbourhood...our common life.

Over the last six years, ASNI has organised a variety of cultural activities, such as concerts in public and private spaces, a street parade with various new urban movements and activist groups, place-making activities and workshops in local schools and public spaces (e.g. urban gardening), cultural mapping workshops, artistic and tactical urbanism interventions (e.g. street zebra), memory nights, thematic walking tours, a movie festival on urban commons, a reading group entitled 'Cities and Literature', a revival of a local carnival, a picnic for the "global Degrowth day", solidarity actions (e.g. 'save the water' campaign, refugee support), and place-identity fundraising (e.g. neighbourhood annual 
sticker). The most successful activity so far been has been the organisation of a collective dinner: it has not only promoted the transfer of a cultural practice from Spain to Greece, but it has also allowed the creation of a gregarious community network of residents, shopkeepers and local institutions. Currently, ASNI is creating a DIY Pocket Park, through participatory methodologies and is also initiating a Memory Bank. These projects presuppose the existence of informal and loose networks that operate as experimental laboratories for the articulation of identities and the production of culture (Melucci 2009).

ASNI's narration draws on Charles Baudelaire's poetic flâneries and "celebrates the city as an 'allegorical' place where the phantasmagoria of mass culture mixes with the melancholia of everyday life" (Benjamin 1997 as cited in Lowry et al. 2015: 319). Respectively, the Initiative approaches the neighbourhood's space as an urban laboratory. This empirical approach to urban space claims to engage and learn about a city's everyday life, including its neighbourhoods and focuses on the different meanings of public space, which is directly affected by the crisis in every aspect (social, cultural, political, economic) of everyday life. Accordingly, ASNI tries to recreate a local public sphere, not only at neighbourhood but also at the city-wide level, and attempts to produce different uses, perspectives and significances of the urban landscape. For this reason, it evaluates the capacity of Common Pool Resources, such as neighbourhood-based organisations and networks, highlights and fosters potential synergies in the micro-environment of the neighbourhood with combined actions in public space (Chatzinakos 2016). Gradually, this approach enabled the Initiative to capitalise on place-based dynamics by mapping and constantly reinventing an inclusive, yet highly diverse network of assets, within a peculiar neighbourhood-scale symbolic economy. According to Zukin $(1988 ; 2010)$ the scope of the symbolic economy can be used in order to explore how people develop a sense of place and value their neighbourhoods. In this project, this value emanates from the social constructs of place, the cultural understandings of the particular place and the conscious choices people make regarding its use.

\section{Methodology: Linking Theory to Action}

The overall methodological approach of the project is informed by action research and activist ethnography (Plows 2008; Sutherland 2013). The starting point of this longitudinal research was inspired by Svolou $\mathrm{TV}^{69}$ a journalistic audio-visual street project that was already conducting research on a local level in 2013; publishing several short films on YouTube. In the period examined a distinct mode of inductive knowledge co-production was generated through interviews, focus groups, participant observations, cultural mapping, surveys,

${ }^{69}$ ASNI official Facebook page: https://www.facebook.com/geitonia.svolou/. Last access 20 November 2019. 
questionnaires and audio-visual projects. ${ }^{70}$ This gradually enabled the development of a more credible argumentation through a scientific, evidence-based ontology and created a broader space for discussion across a range of disciplines including urban geography, anthropology, sociology, cultural studies, community economics, environmental studies, history, early childhood education, urban planning and so on.

At this point, it should be noted that the data presented here is auto-ethnographic (see Dashper 2016) in its intention and thus reflects upon the author's own engagement with ASNI. In this respect, the data presented is done so in a manner which bears in mind the blurring of boundaries between the researcher and the researched, not least given the fact that the researcher is also an activist who grew up in the particular locality. In terms of reflexivity then, Maguire's (1988: 190) advice that the 'sociologist-as-participant must be able to stand back and become sociologist-as-observer-and-interpreter', has been particularly helpful. In other words, the data reflects Beck's (1995: 15) model of reflexive modernity, and seeks to reconcile "the science of data and the science of experience through real world experiments".

In order to avoid "the sharp separation between the academic world and the world of practice" (Whyte 1989: 382), the overall research approach is built around the concepts of people, power and praxis (Finn 1994). It thus incorporates research design, analysis, reflection and action (Finkel \& Sang 2016) including various methods which can be employed. Participatory research often involves multiple instruments and techniques and is often utilised in conjunction with mixed methods, such as interviews, focus groups, and/or surveys. One of the key elements of participatory research is the equitable partnership approaches to planning and conducting the research in conjunction with community members and/or community-based organisations. The basic assumption of the research is to take social science closer to society and provide an intersection between practice and theory; enabling in such a way an iterative process that reflects and is shaped by the context of the lived experience. One of its key elements is the equitable partnership in planning, as well as conducting the research in conjunction with participants who "effectively mix, sequence and integrate appropriate tools to support genuine dialogue and the exercise of reason in real settings, including complex situations marked by uncertainty and the unknown" (Chevalier \& Buckles 2013: 7). For this reason, it focuses on individual participants who are involved actively in the production of knowledge and emphasises their full involvement at every stage of the research process. In this sense, this research is being conducted and developed together with participants, who combine different skills interdisciplinary, constructively and complementarily in a process of mutual dialectical understanding.

${ }^{70}$ ASNI Youtube channel: https://www.youtube.com/channel/UC6Yn4bZN iZ00AN7JvG_kQiw. Last access 20 November 2019. 


\section{Alexandrou Svolou: An Ordinary Neighbourhood?}

The neighbourhood of Alexandrou Svolou is located within the administrative boundaries of the $1^{\text {st }}$ Municipal District, which is comprised of five subneighbourhoods that include the historical (landmark monuments), administrative (City Hall), cultural (museums) and commercial centre of Thessaloniki (Figure 1). However, those sub-neighbourhoods $(\Sigma 1, \Sigma 2, \Sigma 3, \Sigma 4, \Sigma 6, \mathrm{M} 1$, Figure 2), are not officially recognised as separate units by the city's administration. For this reason, ASNI demarcated an area of broader interest and named it after Alexandrou Svolou Street, a central mild-traffic axis that lies between the two major streets of the city that horizontally divide its historical centre (Figure $2 \& 3$ ). The urban fabric can be characterised as continuous, interrupted only by several vertical streets and pathways. The area is characterised by high density housing that follow the model of vertical social segregation, a typical characteristic of the Greek city (Maloutas \& Karadimitriou 2001) (Figure 4). Although it is a relatively residential neighbourhood that mainly houses middle class families, the elderly and students, it is full of cultural life and spaces of consumption. Analysing the position of the neighbourhood and its relationship

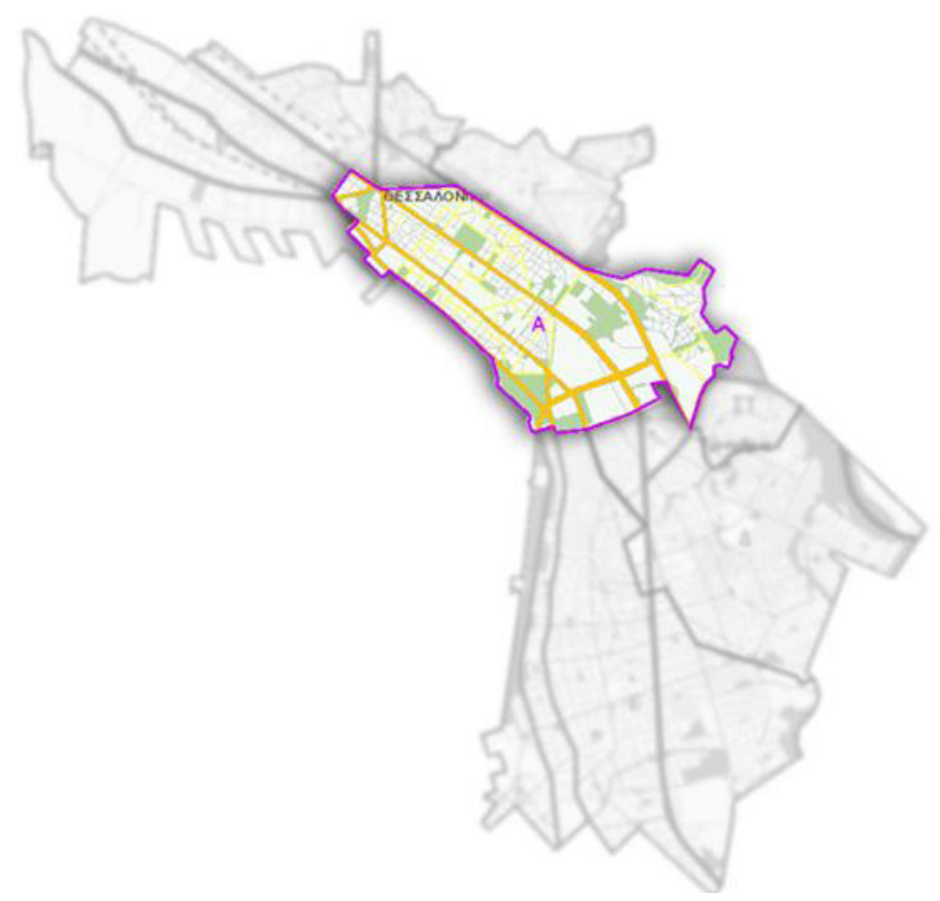

Figure 1: The administrative boundaries of the $1^{\text {st }}$ Municipal District (Source: Municipality of Thessaloniki). 


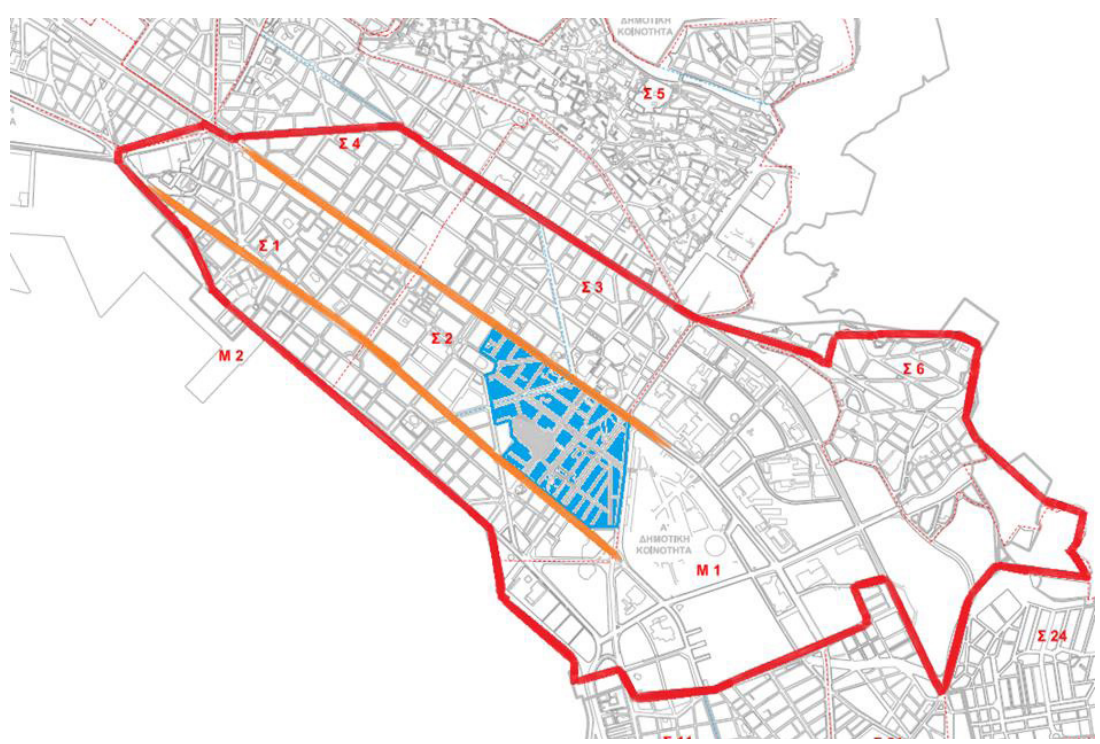

Figure 2: With red: the boundaries of the $1^{\text {st }}$ Municipal District. With orange: the two main streets of the city (Tsimiski \& Egnatia str.) that divide the historical centre. With blue: the sub-neighbourhood of Alexandrou Svolou (Source: Municipal Department of Urban Planning \& Architecture, edited by the author).

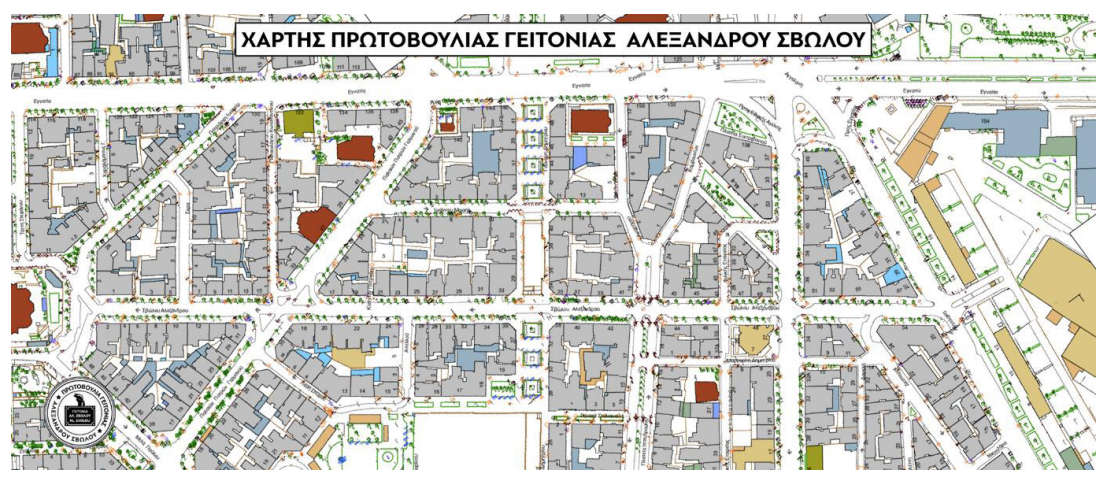

Figure 3: Alexandrou Svolou's Neighbourhood, according to ASNI (Source: GIS Thessaloniki, edited by Periklis Chatzinakos).

to the broader city, one must take into account its proximity to the Aristotle University, the Municipal Central Library, the International Helexpo, the History Centre of Thessaloniki, the church of Hagia Sofia, the Arch of Galerius 


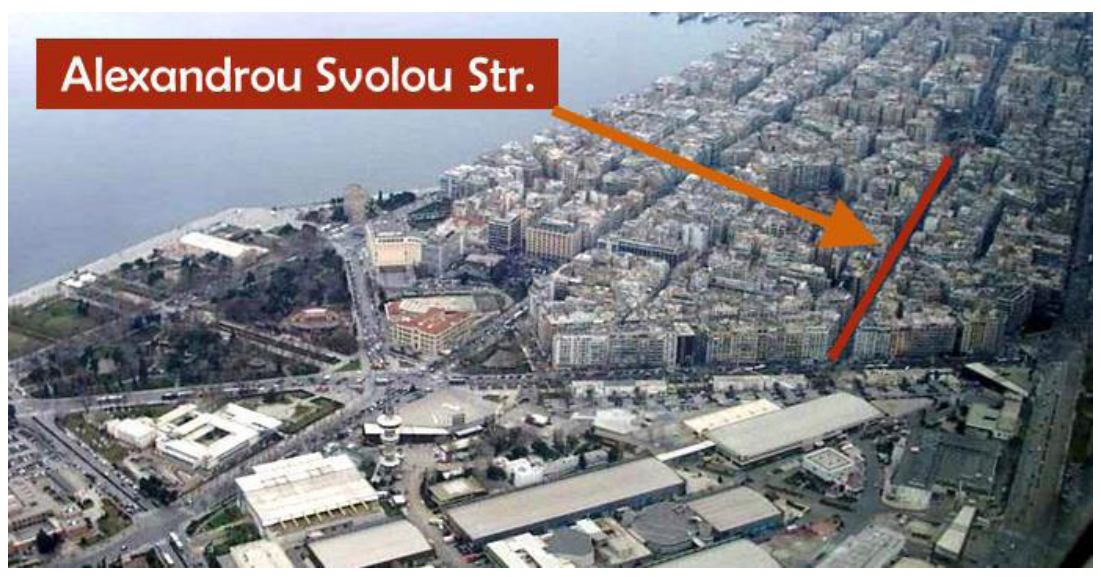

Figure 4: An aspect of the historical centre of Thessaloniki (Source: Airphotos. gr, edited by Lazaros Chatzinakos).

and Navarinou Square. ${ }^{71}$ Apart from this square, of city-wide importance and consisting of a public space that has traditionally been shared by a mosaic of different sub-cultures and urban tribes, there is a significant lack of open and green spaces. In order to provide an in depth understanding of the geographical specificities of the particular neighbourhood, the most ideal approach would be a detailed, demographic analysis of specific administrative boundaries. However, quantitative data is not available for the sub-area under consideration. The only census data available is the total population of the $1^{\text {st }}$ Municipal District, ${ }^{72}$ which is considered too large an area for the focus of this study. It must be noted that in Greece it is not common for researchers and/or residents to be afforded access to demographic data through open-source neighbourhood monitoring systems, as is the case in many other cities around the world (e.g. Brussels, ${ }^{73}$ Manchester, ${ }^{74}$ Vienna ${ }^{75}$ etc.). For this reason, the empirical understanding of the social landscape of the neighbourhood is shaped through the qualitative elements of the research, such as interviews, observations and secondary sources.

${ }^{71}$ Navarinou square is emphatically characterised by a local musician as the "centre of the entire world". https://www.youtube.com/watch?v=3zEaLO 60Bik. Last access 20 November 2019.

${ }^{72}$ The population of the district is 44.434 people (FEK $718 / \mathrm{B}^{\prime} / 21.05 .2014$ ).

73 Website: https://monitoringdesquartiers.brussels/. Last access 20 November 2019.

${ }^{74}$ Website: https://dashboards.instantatlas.com/viewer/report?appid=962615 537fc24dda8a0a29dc86bd4e37. Last access 20 November 2019.

75 Website: https://www.wien.gv.at/statistik/bevoelkerung/bevoelkerungsstand/. Last access 20 November 2019. 


\section{Searching for the Neighbourhood}

A neighbourhood can be seen as a contested archipelago of objectivity (streets, squares, buildings etc.) and subjectivity (peoples' perception, sense of place, place identity, local heritage etc.). Nonetheless, a single and straightforward definition of what actually constitutes a neighbourhood is difficult to capture in simple terms. Such a broad use of the concept "has a transcendent nature and cannot simply be equated with particular groups or a place. Nor can it be reduced to an idea, since they do not simply exist outside social relations, socially-structured discourses or a historical milieu". Even if there is a lack of a broad consensus, a neighbourhood can be associated with the sense of reciprocity and collective action within a delimited space and is based on an underlying expectation that an urban community might exist in the arena of residential life (Martin 2017: 79). Subsequently, a neighbourhood captures the idea of social interaction, since as a term it highlights propinquity as the primary dimension of urban social relations.

However, even if the notion intuitively involves spatiality and it is widely acknowledged that it affects locals in a special way, precise measurement of this spatial dimension is often treated as problematic (Spilsbury et al. 2009). Moreover, when identified, neighbourhood impacts are often small in magnitude, leading to controversy about whether such effects actually exist (Dietz 2002; Sampson et al. 2002; Sellström \& Bremberg 2006). Still, a neighbourhood can be defined also as an experience, not limited to specific geographical constraints. Relatedly, in order to invoke the notion of neighbourhood as a commoning practice, one has to recognise that it is real and material as well as an ideal. It is both an experience and an interpretation (Wagner 2008). In this sense, a neighbourhood can be approached not just as a practice constructed by mental or even physical boundaries, but as having a symbolic character, which to a certain extent creates links between different social sub-groups (Turner 1969; Cohen 1985). In such a way, it can be seen as a symbolic unity composed by practices, shared symbols and values that allows its members to form a collective consciousness.

In summarising this short overview of different concepts about the neighbourhood, one could agree that the different uses of the term are inevitable. The main reason this project embraces the concept of the neighbourhood is that community-building at a local, decentralised level can be seen as a response to the crisis, engendering solidarity and belonging, notions that have been 'exacerbated' and at the same time induced by globalisation (Delanty 2009). Subsequently, even if the particular neighbourhood does indeed have some geographical limits, the overall research approach has mostly focused on the relational and symbolic aspects of the definition; involving relationships that do not depend solely on physical proximity. In other words, this project considers an Aristotelian perspective that views the 'neighbourhood' as a civic society of mutual interdependence and reciprocity, a kind of social co-existence comprised 
by diverse individuals that live, share and use common resources and public space. According to this conceptualisation the neighbourhood is approached as a micro-sociological context within a particular locale, in which a broader crisis - entailing long-lasting insecurity, despair and alienation - is played out. This pertains to both processes of space production and forms of social reproduction (Lefebvre 1991); allowing for the creation of "a space designed for interactions between an urban context and a research process to test, develop and/or apply social practices" (Voytenko et al. 2016: 3). In this light, the locality (a neighbourhood) becomes not only the setting but also the means for collective experimentation with possible alternative forms of social organisation.

\section{Challenging Conventional Strategies through Urban Experiments}

"Nobody knows the answers to city living in the future, and, when answers are unknown, experiment is essential" (Spilhaus 1967: 1141).

Urban experimentation is an emerging field of practice, and one that has come rapidly to prominence across a broad spectrum of practice and thought. The term has been used broadly to reshape practices of knowledge production in urban debates, across different regions and cities. An urban experiment can be defined as a flexible set of practices that centre on processes of social change, and on the emergence of new practices and concepts that constitute belonging (Karvonen \& van Heur 2014: 380). Every experiment can be analysed according to "the degree to which it is inclusive, systematic, practice-based, challenge-led, a site of social learning and adaptive in the face of uncertainty and ambiguity" (Sengers et al. 2016: 26). The latter, are seen as places for representing, encountering, incorporating and researching aspects of cultural difference. Essentially, the symbolic significance of an experiment can attempt to modify the concepts of perception and appreciation of the social world; making "visible the ways local stories, practices, relationships, memories, and rituals constitute places as meaningful locations" (Duxbury et al. 2015: 19).

Furthermore, there is a growing effort to situate urban experimentation as a mode of governance within a broader understanding of the material and political production and reproduction of cities and parts of cities (Evans et al. 2016). Previous research demonstrates that such interventions, either organised in a top-down or bottom-up fashion, managed to increase participation in neighbourhood-based activity, changing the spatial and social environment of various cities (Zenk et al. 2009; Kinney et al. 2012; Brindley et al. 2014; Dulin Keitaa et al. 2016). In this sense, place-based experimentation can offer novel modes of engagement, governance and politics that both challenge and complement conventional strategies. 
Nevertheless, as urban experimentation has become an important way of understanding and governing the city and of trying to steer processes of urban change in specific directions, "the social inclusiveness and disruptive potential of the 'improvements' sought through experimentation begs more critical scrutiny" (Evans 2016: 430). Even if researchers have been studying this phenomenon for quite a long time, only recently have urban geographers brought a range of new terms and ways of thinking about urban experiments to contemporary cities (Evans \& Karvonen 2011; Bulkeley \& Castán Broto 2012). According to May \& Perry (2016: 33) whilst urban scholars have examined the 'sustainable' city, less emphasis is placed on the relationships between knowledge production, the city and experimentation from a social epistemological point of view. In other words, there is little research done on how knowledge is implicated within urban strategies and how experimentation is attributed with social value in the context of neoliberal politics. Bearing this in mind, ASNI's approach to experimentation promotes experimental cultural productions that challenge established norms and highlight various networks of opposition to the dominant culture, proposing their own cognitive and evaluative structures (Bourdieu 1984; Melucci 1996; see Souzas 2015: 267). Likewise, experimentation on a neighbourhood level has enabled knowledge acquaintance from real-world interventions and procedures of collective reflection and analysis. Specifically, ASNI has organised three grassroots urban experiments, namely Spring Dinner, Pocket Park and Memory Bank. The rest of the chapter will reflect on the most significant theoretical and empirical outputs these experiments have produced.

\section{Spring Dinner: From One Southern Mediterranean City to Another}

Inspired by a picture of an urban dinner that took place during the Fiestas de Gràcia in Barcelona (Sanclemente 1990; Sobrequé 1996; Lafarga, 1999; Mercado 2004; Crespi-Vallbona \& Richards 2007; Richards 2010) ASNI initiated the Spring Dinner in 2014. In terms of cultural geography, the organisation of the dinner examined whether it was possible to transfer a rooted cultural practice from another southern European city to Thessaloniki in an organic fashion. In other words, the key to this experiment was to adapt this cultural practice to the local identity without diluting it. It is important to note that these cultural practices can be traced in a variety of regions and cities around the world and are considered important cultural practices, with long-established associations with urban culture. In fact, they can be found under different names in cities all across the word (Fiestas del barrio, Nachbarschaftsfest, Fête des voisins, Grätzelfest, Neighbours' day, Dzień sąsiada etc.). Although they might differ from city to city in terms of organisation, social characteristics, 
cultural practices undertaken and legal status ('eventful framework', see Richards \& Palmer 2010), they share some common attributes: urban space, people, identity negotiation, practice as well as evoking cultural heritage. In contrast to this, urban dining was until recently something that was almost unknown in the contemporary urban landscape of Greece and as a result there is a lack of legal frameworks that allow for the appropriation of public space for communal use and culture.

The concept behind an urban dinner is to get the neighbours together to share their food, thus symbolically reclaiming public space. By confronting people with the unfamiliar, this sort of liminality aims to provoke free thinking, selfquestioning, self-discovery and reflexivity (see van Heerden 2011). The concern in this experiment is with the potential that a gathering of this kind has to, temporarily, disrupt the everyday order. In earlier societies liminal rituals, such as the medieval carnival, provided a sanctioned forum for the unleashing of societal tensions, a place where peasants were able to enjoy and consume the surplus produced by the intense labour of harvest (Bakhtin 1984; Turner and Rojek 2001). In this regard, the Spring Dinner aims to transform the neighbourhood from a space of daily routine and monotony into a place of sharing and entertainment. It can be considered a way to discuss the possibility of communitas, which frees residents from the constraints of 'everyday' life and provides both the opportunity and a space for reflection on basic cultural values and norms (see Turner 1982). By following Jepson \& Clarke's (2013: 3) definition of community festivals, the Spring Dinner is a "themed and inclusive community event or series of events which have been created as the result of an inclusive community planning process to celebrate the particular way of life of people and groups in the local community with emphasis on particular space and time". It can be framed by five essential characteristics: (1) the performance of cultural symbols, (2) sharing and entertainment, (3) it is undertaken in a public place, (4) it reclaims urban space for community use and (5) it constitutes a social strategy to combat the growing alienation and insecurity felt in public space (see Hughes 1999).

The first Spring Dinner was not holistically embraced by the neighbourhood. However, it did produce some social links between different individuals, groups and institutions, which in the past did not have any form of synergy. Essentially, locals, shopkeepers and community groups who previously did not know each other, gradually, established a new sense of confidence and conviviality; encouraging a stronger interaction between existing community organisations and activist networks. This was achieved not only through their participation but also through active involvement in the organisation of the dinner (a period of approximately 5 months). In this regard, cultural production and consumption can produce a sort of profound social interaction, with identifiable social consequences and impacts, providing people with an opportunity to get to know each other better and develop an interactive relationship with 


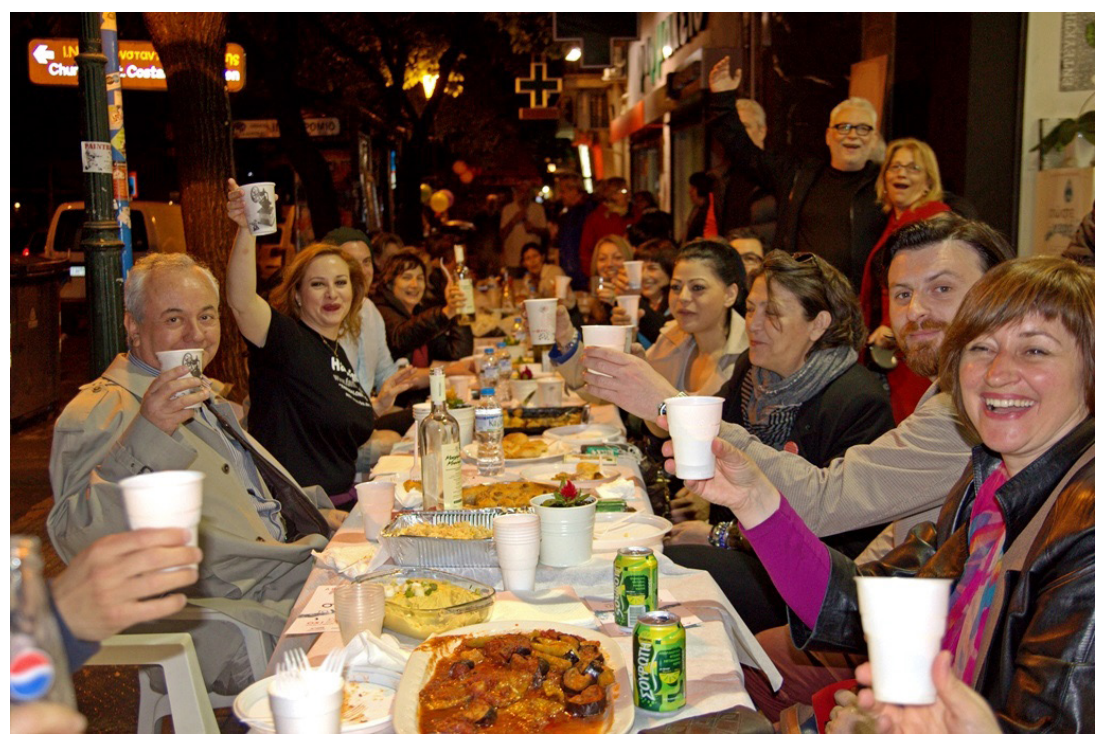

Figure 5: The $1^{\text {st }}$ Spring Dinner in 2014 (Source: Eleni Vraka).

public space. With the passage of time, ASNI established a flexible event management plan by experimenting with different research approaches and methodologies, mixing various 'good practices', and effectively integrating the local creative capital and its socio-cultural attributes. Subsequently five consecutive Spring Dinners, variations on the above model, have taken place on an annual basis. Since 2016 each dinner has attracted around 5,000 people, including local musicians and artists. It would seem that this pilot urban experiment created a more fertile ground for carrying out further activities and, indeed, is nowadays considered to be a benchmark in the city. ${ }^{76}$

Nevertheless, it should be noted that the Spring Dinner is a standalone one-day event. Essentially, each year ASNI builds an urban stage, a theatrical scenery that for a few hours converts the neighbourhood into a highly diverse street ballet set (Jacobs 1961). Despite the socio-cultural mixing and the appropriation of public space, there is the danger that this could create a feeling of managed or "staged culture" (MacCannell 1973). Such a feeling might remind one of a theatricalised and aestheticised city, not one that has been built up organically (Williams 2004). However, ASNI considers these urban dinners not an end in themselves but as a means to create a different/temporary atmos-

${ }^{76}$ In 21.06.2016 the Mayor Yiannis Boutaris invited the citizens of Thessaloniki to take more initiatives in order to improve their everyday life, through a rhetoric of 'citizenship', using as an example Spring Dinner. 


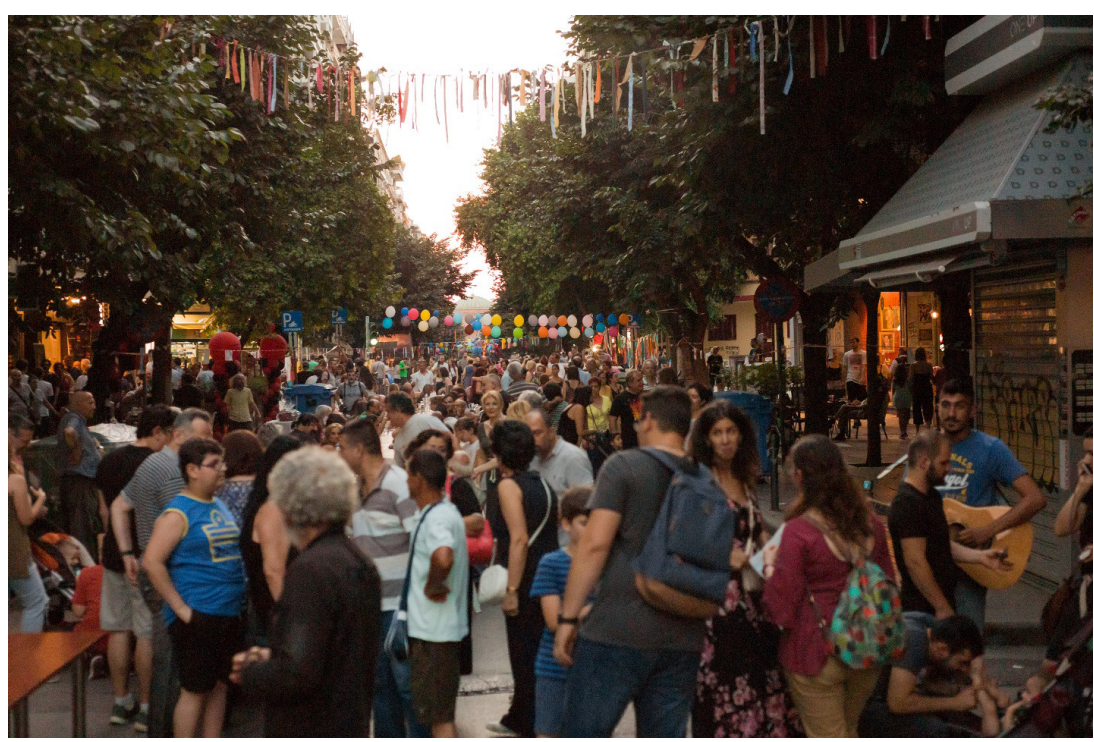

Figure 6: The $3^{\text {rd }}$ Spring Dinner in 2016 (Source: Argiris Karagiorgas).

phere in a stagnant and crumbling reality. In this sense, although the dinner constitutes a heterotopic performance that creates a short-term community, its focus is on the 'next day' and the potential changes in social attitudes and perceptions. The concern here is how far the Spring Dinner has managed to provide the foundations for more diverse networks (extrovert or introvert) that might add to an evolving but gradual process of neighbourhood-building, connecting people to their locality over a period of time far beyond the confines of the event itself.

\section{Pocket Park: From Participatory Planning to Participatory Action}

The reflective evaluation that followed the $3^{\text {rd }}$ dinner in 2016 raised the questions as to whether its impact was sustainable throughout the rest of the year and whether such a non-permanent and culturally produced intervention is enough to contribute towards a deeper experiential appropriation of the neighbourhood. Bearing this reasonable limitation in mind, ASNI discussed ways of achieving a more permanent presence and further visibility in the neighbourhood. Undeniably, the creation of a self-managed space would serve as a meeting place for collective action. To this end, the Initiative decided to engage with student groups (Iliopoulos \& Kaligas 2017) by focusing on and appropriating an urban 'void' located in the neighbourhood. 


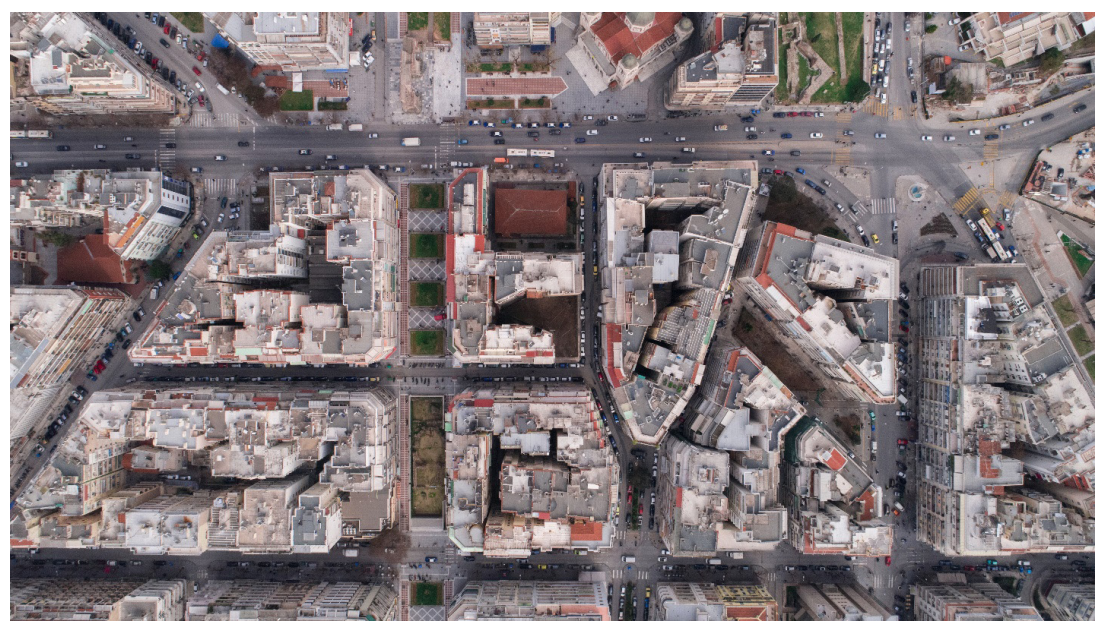

Figure 7: The urban 'void' from above (in the centre) (Source Vaggelis Ameranis, The White Dot).

What is particularly significant about this urban 'void' $\left(431,65 \mathrm{~m}^{2}\right)$ is its ownership regime. It consisted of a vacant piece of public land that had been left to become derelict. $70 \%\left(337,05 \mathrm{~m}^{2}\right)$ of its total area belongs to the School Buildings Organisation SA, a state-owned public limited company based in Athens, with the other $30 \%\left(94,60 \mathrm{~m}^{2}\right)$ belonging to the Municipality of Thessaloniki. A reasonable question that arises from this situation is why an urban 'void' should belong to two public institutions? Why would the Municipality of Thessaloniki purchase a piece of wasteland from another public institution, especially when this space does not have any other apparent use other than landfill? Comparative research on other cities revealed the remarkable fact that, for example, in Helsinki (Finland) all the public land belongs to the city itself, whilst the revenue from public services (see Helen Electricity Network Ltd) is mostly reinvested back into the urban fabric. In contrast, Greek cities seem to be unwilling or incapable of managing their urban fabric. Therefore, the creation of this space is highly relevant in relation to urban planning and the production of alternative spaces, while also holding the potential to encourage more inclusive and democratic forms of planning.

Essentially, this experiment consists of a collective effort to convert an urban 'void' into a pocket-sized neighbourhood park through a social process of commoning. In order to kick-start this activity, ASNI organised a participatory planning workshop in its premises in the $1^{\text {st }}$ Municipal District of Thessaloniki. This workshop offered 'average residents' an effective outlet for collective and creative expression. Subsequently, in order to engage with the broader neighbourhood, the Initiative organised a number of campaigns, placing 


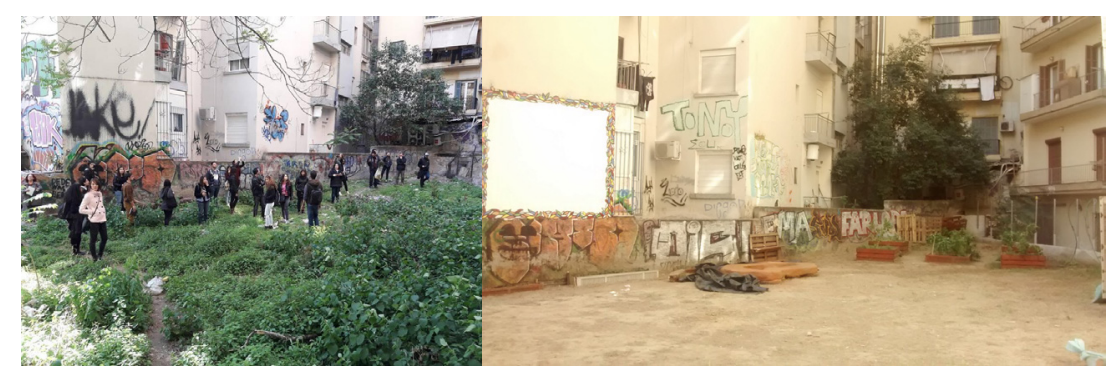

Figure 8: (left): How the space looked at the time of the participatory planning workshop in 22.04.2017 (Source: Maria Stefanouri), (right): How the Park looks now, about a year and a half later (Source: Anthi Antoniadi).

information points in various spots in the locality and collaborating with the local primary school. Passing from participatory planning to participatory action, the Initiative has so far organised 9 consecutive 'construction acts' (cleaning, embankment fill, urban garden, plantings, cob workshop, self-made urban infrastructure/benches, gym, entrance, feeders for stray animals) and a variety of cultural events (fundraising concerts, a summer cinema, collective dinners, workshops, artistic performances etc.) demonstrating a particular appetite for community engagement along the way. Despite profound bureaucratic limitations, ${ }^{77}$ ASNI is still developing this project, without any external sources of funding. The methodology that was used is considered groundbreaking for the city, as there have been no other cases effective bottom-up participation in urban planning.

Thus far, the main challenge that has emerged through this experiment is finding ways to build trust with the surrounding urban micro-environment, breaking the negative impacts of vertical and horizontal social segregation. Arguably, this approach will assist socio-spatial appropriation on a regular basis whilst avoiding exclusionary or elitist practices.

\section{Memory Bank: Towards a more Conscious Local History}

In 2018, ASNI initiated a Memory Bank in an attempt to highlight the role of memory on an individual and neighbourhood level. The aim of this project is to identify and crystallise elements that can shape a more conscious and intimate historical and experiential knowledge, involving locals in "the creation of their own history" (Grele 1985: xvi). Together with the Greek Oral History

77 The Kallikratis reform (Law 3852/2010), for instance, does not illuminate in detail how citizens can actually participate in decision making and urban planning. For further scrutiny see Katsoulis 2011:4). 


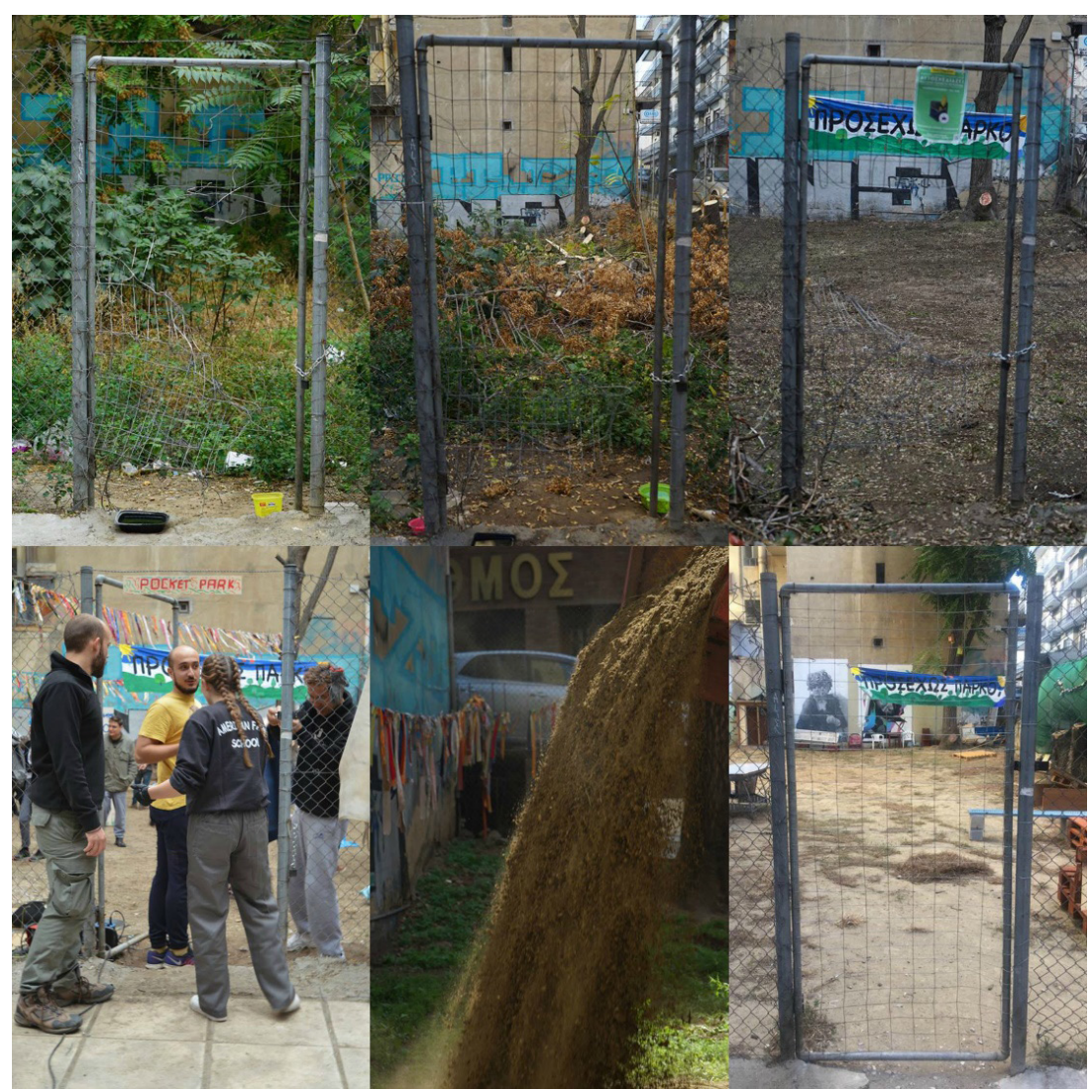

Figure 9: The gradual transformation of an urban 'void' (Source: Periklis Chatzinakos).

Association, ${ }^{78}$ ASNI organised an introductory seminar that took place in the Municipal Central Library. The seminar aimed to familiarise participants with the theoretical, methodological and ethical aspects of oral history. Oral history is closely linked to local cultural heritage, since it is

"built around people... It brings history into, and out of, the community. It helps the less privileged, and especially the old, towards dignity and selfconfidence. It makes for contact - and thence understanding - between social classes, and between generations... It can give a sense of belonging

${ }^{78}$ Official website: http://www.epi.uth.gr/index.php?page=aboutus. Last access 20 November 2019. 


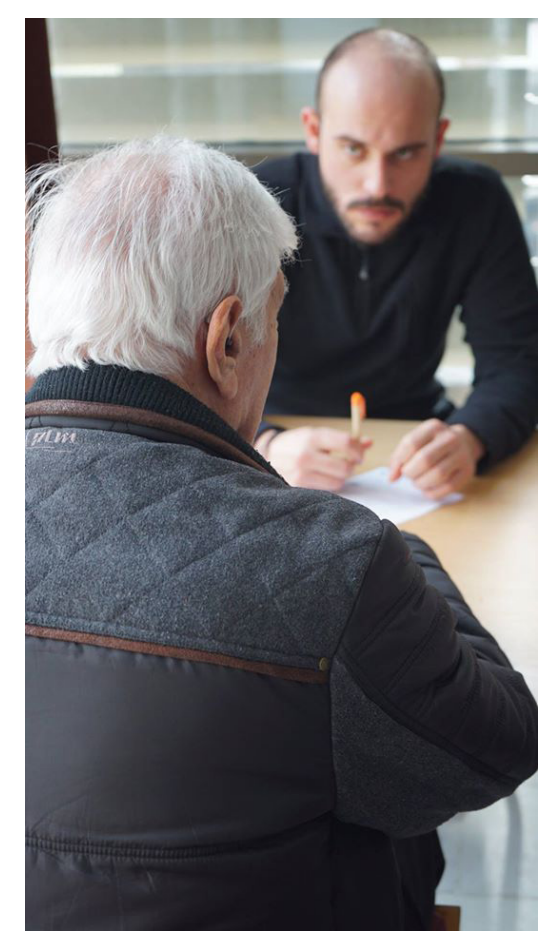

Figure 10: A two days seminar on oral history in the Municipal Central Library (Source: author).

to a place or in time ... It provides a means for a radical transformation of the social meaning of history" (Thompson 1978: 18).

The main influence behind this urban experiment lies in Burnage, a workingclass suburb of Manchester, where local groups and individuals try to collect, share and celebrate the stories of their place of residence. In a similar fashion, ASNI's Memory Bank has started to collect personal narrations, stories, local myths and archival material (bibliography, photographs, postal cards, newspapers, personal letters, etc.) and the intention is to deposit them in an open-source platform (see Burnage Memory Bank ${ }^{79}$ ). The aim is to "include within the historical record the experiences and perspectives of groups of people who might otherwise have been hidden from history" (Perks \& Thomson 2006: ix). Such an approach can develop intercultural story-telling, memory

${ }^{79}$ Official website: http://www.burnageactivityhub.org.uk/wp/?page_id=1306. Last access 20 November 2019. 


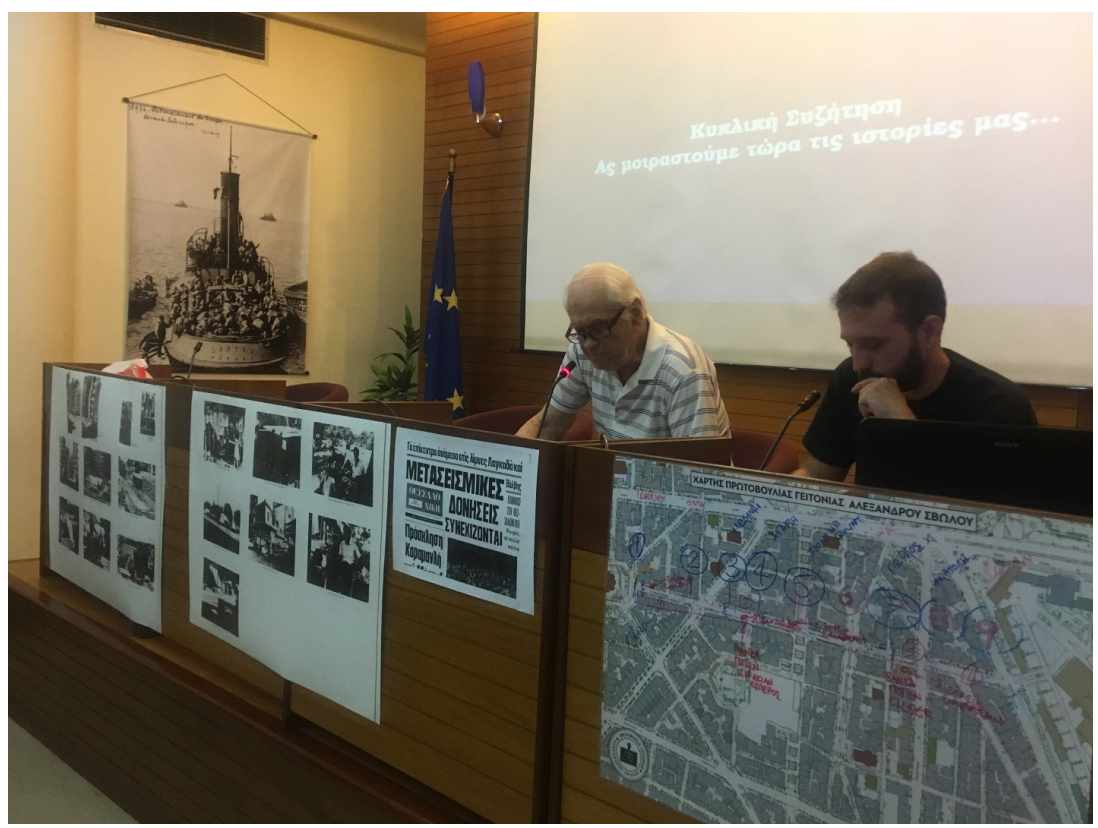

Figure 11: 30 years from the Earthquake of 1978: A Night of Memory in the History Centre of Thessaloniki (Source: Periklis Chatzinakos).

visualisation and aestheticisation, making it possible to reclaim the neighbourhood as a "collective work of art" (Lefebvre 1996: 174).

\section{Discussion: From Cultural Production to Neighbourhood Commoning}

In a world where notions of culture are becoming increasingly fragmented, such experiments and cultural practices have gained an important position when it comes to the consumption of the city (Ritzer 1999). However, the mass standardisation of cultural production and consumption that lie at the very heart of the contemporary city (Miles 2017), has led to phenomena that have been characterised variously as the "serial reproduction of culture" (Harvey 1989), "placelessness” (Relph 1976), “non-places” (Augé 1995) and so forth. Within a continuously globalised environment, places start to look the same and the ability to create the sense of "uniqueness" within a city diminishes (Richards \& Wilson 2006). As Zukin (2011) points out, the more contemporary cities have sought to distinguish themselves from one another, the more they have in fact ended up looking and feeling the same. Within this emerging geography of connectivity there is a growing tension between culture as something 
grounded in place and culture as a pattern of non-place globalised events and experiences (Scott 2000).

Although the experiments presented here are very similar to corresponding practices that take place across the world (e.g. urban dinners, DIY parks, memory banks etc.), it can be said that they are trying to adapt to the existing social resources and local dynamics. Even though they consist of a pluralistic mosaic of different cultural practices, their main feature is that they constitute a significant aspect of the socio-economic and cultural landscape of everyday life. Key to their transfer is the extent to which such cultural events previously held in other cities can be replicated in such a way as to not dilute the unique nature of the local identity (Richards \& Wilson 2006). Arguably, if a community maintains its proactivity, creativity and inclusive character, it can retain its identity without being alienated by the global massification, since "people are the ones making a cultural practice unique and not the practice itself" (Chatzinakos 2015: 50). This approach can bypass the limitations derived from the codified definitions of culture and engage in practice with different experiences and representations, derived directly from the neighbourhood's "collective imaginary" (Castoriadis 1987).

Thus, in a variety of ways these urban experiments build-up expertise and a capacity for urban commoning practices, while serving as a process for collective reflection on communal issues and problems and providing an open platform for locals to meet and share their thoughts. ASNI has developed a model of direct democracy where social relations are organised around place, urban identity, peer to peer knowledge exchange and intersectionality, without any hierarchical regulation imposed by a legal framework. In this sense, this paradigm of neighbourhood organisation can be considered to be an informal social structure that aims to integrate objective and subjective considerations of reality. This can assist, to a certain extent, in the creation of a relational and interactive collective identity (Melucci 2009), which is embedded in a shifting social-cultural and political context. The latter is not proposed as a consolidated, rigid, homogeneous and integrated reality, but rather as a changing context characterised by emotion, diversity and flexibility, a subject of continuous construction and re-construction. It constitutes both a dynamic space of relationships that crystallises the effects of collective action and a springboard for action (see Souzas 2015: 268). Therefore, it only truly exists in a state of permanent and dialectic re-invention.

Overall, the research presents elements that can potentially enhance the skills and the resources of a community, dismantle barriers and isolation through active engagement; promoting community self-governance and knowledge exchange. This process allows participants to understand the importance of initiative and taking action. Essentially, this longitudinal activist project aims to create an identity effect that will enable locals to become more aware, re-evaluate, regain, and/or strengthen their sense of place through an empowering process. Chiesi \& Costa (2015) argue that this identity effect can be intangible but 
very significant. It is related to a process that allows for the emergence of a shared view regarding strategies to promote local culture, a detailed definition of local needs related to social and cultural necessities, a raised awareness of the importance of local cultural heritage and deeper spatial and place-based understandings. This process might enable a growing synergy among locals in public space, acquiring an in-practice understanding of the importance of cooperative practices in solving common social issues, enriching cultural and spatial imaginaries. However, every neighbourhood and place is different, with unique characteristics and particular dynamics. Therefore, even if the experiments presented can be transferred and replicated further, the findings cannot be generalised.

Additionally, from this perspective there is a danger of seeing the topic either in a personal and even biased light or in an institutionalised fashion that might dilute community dynamics and spontaneity. This experimental approach should take place on an ontological level, far from normative. As Caprotti \& Cowley (2017: 1445) critically note, in some cases an urban experiment might lend itself to a potentially normative epistemological approach to the city: presenting the city as a set of variables, a messy set, but still a collection of parameters that can be tinkered with and controlled. In this direction, the experiments presented are being developed in parallel with all the surrounding material conditions, which include the creation of shared cultural meanings, social interaction, and community engagement. Neighbourhood-building depends on a variety of processes and critical factors, while social transformation is an ongoing process that can not solely solve structural inequalities. Arguably, the quest of belonging is the inevitable process of meaningful re-production. Therefore, future research should pay attention to the motivations and meanings participants develop i.e. devotion, perseverance, dialectics, language, power relations, conflict-resolution, critical evaluation, reflection and realisation of the overall set aims and objectives.

\section{Conclusions}

This chapter highlights the role that key neighbourhoods can play in urban management and local governance. It can be argued that cities taking advantage of the liminal attributes provided by urban experiments can develop a municipal strategy based upon the promotion and expansion of urban commons and social solidarity. In such a way, cities can actually use urban experimentation in their favour, overcoming specific challenges they might be facing on a community level, and generating novel, bottom-up solutions that respond effectively to the local socio-cultural contexts, engendering a sort of neighbourhood culture. If respective neighbourhood initiatives flourish then they can create a domino effect, leading the history of a city into a new era of participation and solidarity, challenging social conventions, strengthening social ties 
and creating a new relationship with public space. Nevertheless, when faced with everyday lives that are heavily personalised, the reproduction of this social structure cannot alone provide a practical approach to neighbourhood organisation. This can only happen when respective commoning practices start to flourish, becoming important pre-figurations of an emancipated society. Urban commoning must remain a collective struggle to re-appropriate and transform 'at the same time' a society's common wealth (Hardt \& Negri 2009: 251-253), extending this structure beyond its own limits. This entails an approach that is consultative, informed, and democratic, and which considers both the whole population (past, present, future) and culture in all of its diverse and collective manifestations (Evans 2015). Such an approach may provide the basis for the development of further approaches to resident empowerment and participation, by encompassing a variety of sustainable, locally based, place-making projects that promote neighbourhood-building and more inclusive urban futures.

This project makes the case for more effective and decentralised governance capacity. Accordingly, the long-term outcome of the project discusses a common reflection that concerns the future of the Greek city, given the fact that during financial crises, cities are not only the epicentre, but also the context that shapes residents' daily routine and their relationship with the urban fabric (Harvey 2012). In terms of urban management, activism and local level research reveals the main limitations, trends, hegemonic norms, and issues experienced in practice. These include the lack of an open-source neighbourhood monitoring system and the absence of a framework that supports locally organised collective action in urban planning and culture. As a result, in Greece, citizens do not have the opportunity to participate in local governance and collectively address the problems of their place of residence. Therefore, they cannot (re-) produce applicable actions in a bottom-up fashion that may provide practical solutions and physical improvements to shared spaces.

Nonetheless, the potential of such bottom-up neighbourhood initiatives may foster a more locally-based participatory and activist culture that can be associated with the creation of a different urban identity: one that is built around urban commons and is created by the people, instead of being imposed upon them. Long's (2013) argument on the sense of place, drawing on Massey (1994), tells us to pay close attention to the cultural specificity of places; the myths, narratives and memories that surround them, and the cultural production that is shaped by them. In this regard, this project highlights the fact that if a city is considered to be a common (Pusey \& Chatterton 2017), it can be governed by and for its residents to maximise internal democracy and well-being (see De Angelis 2007; Linebaugh 2008). The priority then is to create a systematic approach for effective and efficient group collaboration on neighbourhood level, thereby ensuring improved decision-making in urban-scale politics. To this end, it is peoples' ability to work together that this longitudinal research seeks to understand by setting the foundations for common urban futures in the 'real' world. 


\section{Acknowledgements}

I would like to express my warmest thanks to all the magnificent people from the Alexandrou Svolou Neighbourhood Initiative. This long-lasting journey would not have been possible without you. My deepest appreciation goes to Giorgos Synefakis, Aikaterina Georgiadou and Periklis Chatzinakos whose companionship, solidarity and invaluable contribution played a decisive role in the development of the project. I am grateful to the guidance and mentoring given by Professor Steven Miles (Manchester Metropolitan University). Through all these years, not only has he been a second father to me, but also a tireless and critical observer of this project. I would also like to sincerely express my gratitude to Eleftheria Deltsou, Stelios Lekakis, Konstantinos Theodoridis and Natalia Natsika for providing me with valuable feedback and constructive comments. This chapter is dedicated to the memory of Lazaros Chatzinakos, a Journalist who believed in a modern society that could maintain the innocence of earlier times. May you travel in tamed seas and rest in power, father.

\section{Bibliography}

Agamben, G. (1993). The coming community. Minneapolis, MN: University of Minnesota Press.

Amin, A. (2004). Regions unbound: Towards a new politics of place. Geografiska Annaler: Series B, Human Geography, 86(1), 33-44.

Athanassiou, E., Christodoulou, C., Kapsali, M. \& Karagianni, M. (2018). Hybridising 'ownership' of public space: Framings of urban emancipation in crisis-ridden Thessaloniki. In S. Knierbein \& T. Viderman (Eds.), Public space unbound: Urban emancipation and the post-political condition (pp. 251-265). New York, NY: Routledge.

Augé, M. (1995). Non-Places: Introduction to an anthropology of supermodernity. London, United Kingdom: Verso.

Bakhtin, M. (1984). Rabelais and his world. Bloomington, IN: Indiana University Press.

Barber, B. R. (2013). If mayors ruled the world: Dysfunctional nations, rising cities. New Haven, CT: Yale University Press.

Beck, U. (1995). Ecological enlightenment: Essays on the politics of the risk society. Atlantic Highlands, NJ: Humanities Press.

Benjamin, W. (1997). Charles Baudelaire: A lyric poet in the era of high capitalism. New York, NY: Verso Books.

Bourdieu, P. (1984). Distinction: A social critique of the judgement of taste. New York, NY: President \& Fellows of Harvard College, Routledge \& Kegan Paul.

Brindley, P., Goulding, J. \& Wilson, M. L. (2014). Mapping urban neighbour hoods from internet derived data. In $22^{\text {nd }}$ GIS Research UK Conference. 
Glasgow, UK, 16-18 April 2014 (pp. 355-364). Retrieved November 20, 2019, from https://www.gla.ac.uk/media/Media_401753_smxx.pdf.

Bulkeley, H. \& Castán Broto, V. (2012). Government by experiment?: Global cities and the governing of climate change. Transactions of the Institute of British Geographers, 38(3), 361-375.

Caprotti, F. \& Cowley, R. (2017). Interrogating urban experiments. Urban Geography, 38(9), 1441-1450.

Castoriadis, C. (1987). The imaginary institution of society. Cambridge, United Kingdom: Polity Press.

Chatzinakos, G. (2015). Community festivals and events in the post-industrial European city: The impact of liminal practices on community-building. Saarbrücken, Germany: Lap Lambert Academic Publishing.

Chatzinakos, G. (2016). Mapping the neighbourhood: Problems, suggestions and approaches to urban futures: A methodological approach to the management of bottom-up community synergies and cultural initiatives. In Rocco, R. (Ed.), Jane Jacobs is still here: Jane Jacobs 100: Her legacy and relevance in the 21st century, 24-25 May 2016, Faculty of Architecture and the Built Environment, TU Delft, The Netherlands (pp. 166-173). Delft, The Netherlands: TU Delft, BK Bouwkunde. Retrieved November 20, 2019, from https://issuu.com/robertorocco/docs/jane_jacobs_report.

Chevalier, J. M. \& Buckles, D. J. (2013). Participatory action research: Theory and methods for engaged inquiry. London, United Kingdom: Routledge.

Chiesi, L. \& Costa, P. (2015). One strategy, many purposes: A classification for cultural mapping projects. In N. Duxbury, W. F. Garrett-Petts \& D. Mac Lennan (Eds.), Cultural mapping as cultural inquiry (pp. 69-85). New York, NY: Routledge.

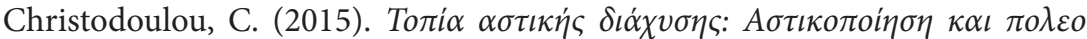

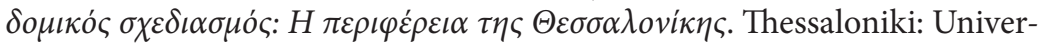
sity Studio Press.

Cohen, A. P. (1985). The symbolic construction of community. London, United Kingdom: Tavistock Publications.

Crespi-Vallbona, M. \& Richards, G. (2007). The meaning of cultural festivals: Stakeholder perspectives in Catalunya. International Journal of Cultural Policy, 13(1), 103-122.

Dashper, K. (2016). Researching from the inside: Autoethnography and critical event studies. In R. Lamond \& L. Platt (Eds.), Critical event studies: Approaches to research (pp. 213-229). London, United Kingdom: Palgrave Macmillan.

De Angelis, M. (2007). The beginning of history: Value struggles and global capital. London, United Kingdom: Pluto.

Delanty, G. (2009). Community ( $2^{\text {nd }}$ ed.). London, United Kingdom: Routledge.

Dietz, R. D. (2002). The estimation of neighborhood effects in the social sciences: An interdisciplinary approach. Social Science Research, 31(4), 539-575. 
Dulin-Keita, A., Hannon, L., Buys, D., Casazza, K. \& Clay, O. (2016). Surrounding community residents' expectations of HOPE VI for their community, health and physical activity. Journal of Community Practice, 84(1), 18-37.

Duxbury, N., Garrett-Petts, W. F. \& MacLennan, D. (Eds.). (2015). Cultural mapping as cultural inquiry. New York, NY: Routledge.

Evans, G. (2015). Cultural mapping and planning for sustainable communities. In N. Duxbury, W. F. Garrett-Petts \& D. MacLennan (Eds.), Cultural mapping as cultural inquiry (pp. 45-68). New York, NY: Routledge.

Evans, J. (2016). Trials and tribulations: Conceptualizing the city through/as urban experimentation, Geography Compass, 10(10), 429-443.

Evans, J. \& Karvonen, A. (2011). Living laboratories for sustainability: Exploring the politics and epistemology of urban transition. In H. Bulkeley, V. Castán Broto, M. Hodson \& S. Marvin (Eds.), Cities and low carbon transitions (pp. 126-141). London, United Kindom: Routledge.

Evans, J., Karvonen, A. \& Raven, R. (2016). The experimental city. Abingdon, United Kingdom: Routledge.

Finkel, R. \& Sang, K. (2016). Participatory research: Case study of a community event. In R. I. Lamond, \& L., Platt (Eds.), Critical event studies: Approaches to research (pp. 195-211). London, United Kingdom: Palgrave Macmillan.

Finn MSW, J. L. (1994). The promise of participatory research. Journal of Progressive Human Services, 5(2), 25-42. DOI: https://doi.org/10.1300 /J059v05n02_03.

Frangopoulos, I., Dalakis, N. \& Kourkouridis, D. (2009). Urban structure and mobility in the context of sustainable development: Citizens' opinion about the Thessaloniki submerged tunnel. International Journal of Sustainable Development and Planning, 4(4), 333-344.

Goodwin, M. (1993). The city as commodity: The contested spaces of urban development. In Kearns, G. \& Philo, C. (Eds.), Selling places: The city as cultural capital, past and present (pp. 145-162). Oxford: Pergamon Press.

Grele, R. J. (1985). Envelopes of sound: The art of oral history ( $2^{\text {nd }}$ ed.). Chicago, IL: Precedent Publishing.

Hardt, M. \& Negri, A. (2009). Commonwealth. Cambridge, MA: Belknap Press. Harvey, D. (1989). The condition of postmodernity: An enquiry into the origins of cultural change. Cambridge, MA: Blackwell.

Harvey, D. (2012). Rebel cities: From the right to the city to the urban revolution. London, United Kingdom: Verso.

Hughes, G. (1999). Urban revitalization: The use of festive time strategies. Leisure Studies, 18(2), 119-135.

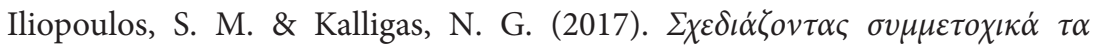

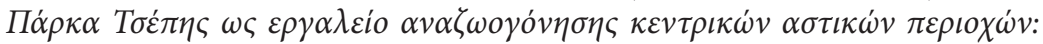

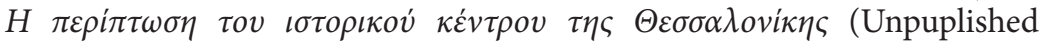
Bachelor Thesis). Aristotle University of Thessaloniki, Thessaloniki.

Jacobs, J. (1961). The death and life of great American cities. New York, NY: Random House. 
Jepson, A. \& Clarke, A. (2013). Events and community development. In R. Finkel, D. McGillivray, G. McPherson \& P. Robinson (Eds.), Research themes for events (pp. 6-17). Wallingford, United Kingdom: CABI.

Karvonen, A. \& van Heur, B. (2014). Urban laboratories: Experiments in reworking cities. International Journal of Urban and Regional Research, 38(2), 379-392.

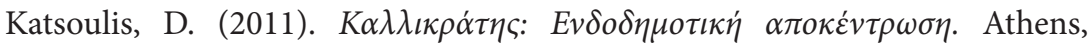
Greece: Elliniki Etaireia Topikis Anaptyxis kai Aftodioikisis. Retrieved November 20, 2019, from https://www.eetaa.gr/ekdoseis/pdf/139.pdf.

Kinney, A. M., Hutton, L., Carlson, B., Perlick, L. M., Minkler, K. K. \& Kimber, C. (2012). Isanti County active living: Measuring change in perception and behavior. American Journal of Preventive Medicine, 43(5), S392-S394.

Kullman, K. (2013). Geographies of experiment/Experimental geographies: A rough guide. Geography Compass, 7(12), 879-894.

Labrianidis, L. (2011). Thessaloniki's arrested development: Missed opportunities. Antipode, 43(5), 1801-1827.

Lafarga, J. (1999). Gràcia: de rural a urbana: Territori i nomenclator. Barcelona, Spain: Taller d'Història de Gràcia.

Lefebvre, H. (1991). The production of space. Oxford, United Kingdom: Blackwell.

Lefebvre, H. (1996). Writing on cities. Oxford, United Kingdom: Blackwell.

Linebaugh, P. (2008). The Magna Carta Manifesto: Liberties and commons for all. Berkley, CA: University of California Press.

Long, J. (2013). Sense of place and place-based activism in the neoliberal city: The case of 'weird' resistance. City, 17(1), 25-67.

Lowry, G., M. S. Levin, M. \& Tsang, H. (Maraya). (2015). Maraya as visual research: Mapping urban displacement and narrating artistic inquiry. In N. Duxbury, W. F. Garrett-Petts \& D. MacLennan (Eds.), Cultural mapping as cultural inquiry (pp. 319-337). New York, NY: Routledge.

MacCannell, D. (1973). Staged authenticity: Arrangements of social space in tourist settings. American journal of Sociology, 79(3), 589-603.

Maguire, J. (1988). Doing figurational sociology: Some preliminary observations on methodological issues and sensitizing concepts. Leisure Studies, 7(2), 187-193.

Maloutas, T. \& Karadimitriou, N. (2001). Vertical social differentiation in Athens: Alternative or complement to community segregation? International Journal of Urban and Regional Research, 25(4), 699-716.

Martin, D, G. (2017). Community. In M. Jayne \& K. Ward (Eds.), Urban theory: New critical perspectives (pp. 74-83). Abingdon, United Kingdom: Routledge.

Massey, D. (1994). Space, place and gender. Cambridge, United Kingdom: Polity Press.

May, T. \& Perry, B. (2016). Cities, experiments and the logics of the knowledge economy. In J. Evans, A. Karvonen \& R. Raven (Eds.), The experimental city (pp. 32-46). Abingdon, United Kingdom: Routledge. 
Mazower, M. (2004). Salonica, city of ghosts: Christians, Muslims and Jews, 1430-1950. London, United Kingdom: Harper Perrenial.

Melucci, A. (1996). Challenging codes: Collective action in the information age. Cambridge, United Kingdom: Cambridge University Press.

Melucci, A. (2009). The playing self: Person and meaning in the planetary society. Cambridge, United Kingdom: Cambridge University Press.

Mercado, B. G. Fl. (2004). "La festa de Gracia sóc jo i jo sóc la festa". La construcción psicocultural de la participación ciudadana en una fiesta popular. Unpublished PhD Thesis. Universitat de Barcelona, Barcelona.

Miles, S. (2017). Consumption. In M. Jayne \& K. Ward (Eds.), Urban theory: New critical perspectives (pp. 99-108). Abingdon, United Kingdom: Routledge.

Oakley, K. (2015). Creating space: A re-evaluation of the role of culture in regenaration. Research Report. University of Leeds. Retrieved November 20, 2019, from http://eprints.whiterose.ac.uk/88559/3/AHRC_Cultural_Value _KO\%20Final.pdf.

Perks, R. \& Thomson, A. (Eds.). (2006). The oral history reader. New York, NY: Routledge.

Plows, A. (2008). Social movements and ethnographic methodologies: An analysis using case study examples. Sociology Compass, 2(5), 1523-1538.

Providência, P. (2015). City readings and urban mappings: The city as didactic instrument. In N. Duxbury, W. F. Garrett-Petts \& D. MacLennan (Eds.), Cultural mapping as cultural inquiry (pp. 217-230). New York, NY: Routledge.

Pusey, A. \& Chatterton, P. (2017). Commons. In M. Jayne \& K. Ward (Eds.), Urban theory: New critical perspectives (pp. 63-73). Abingdon, United Kingdom: Routledge.

Relph, E. (1976). Place and placelessness. London, United Kingdom: Pion.

Richards, G. (2010). Tourism development trajectories: From culture to creativity? Revista Encontros Científicos - Tourism \& Management Studies, 6, 9-15.

Richards, G. \& Palmer, R. (2010). Eventful cities: Cultural management and urban revitalisation. Oxford, United Kingdom: Butterworth-Heinemann.

Richards, G. \& Wilson, J. (2006). Developing creativity in tourist experiences: A solution to the serial reproduction of culture? Tourism Management, 27(6), 1209-1223.

Ritzer, G. (1999). Enchanting a disenchanted world: Revolutionizing the means of consumption. Thousand Oaks, CA: Pine Forge Press.

Robinson, J. (2006). Ordinary cities: Between modernity and development. London, United Kingdom: Routledge.

Sampson, R. J., Morenoff, J. D. \& Gannon-Rowley, T. (2002). Assessing "neighborhood effects": Social processes and new directions in research. Annual Review of Sociology, 28, 443-478. 
Sanclemente, V. (1990). Gràcia: Història de la festa major més gran del pla. Barcelona, Spain: Carrer Gran.

Scott, A. J. (2000). The cultural economy of cities: Essays on the geography of image-producing industries. London, United Kingdom: SAGE Publications.

Sellström, E. \& Bremberg, S. (2006). Review article: The significance of neighbourhood context to child and adolescent health and well-being: A systematic review of multilevel studies. Scandinavian Journal of Public Health, 34(5), 544-554.

Sengers, F., Berkhout, F., Wieczorek, A. J. \& Raven, R. (2016). Experimenting in the city: Unpacking notions of experimentation for sustainability. In J. Evans, A. Karvonen \& R. Raven (Eds.), The Experimental City (pp. 15-31). Abingdon, United Kingdom: Routledge.

Sharpley, R. \& Stone, P. R. (2012). Socio-cultural impacts of events: Meanings, authorized transgression and social capital. In S. J. Page \& J. Connell (Eds.), The Routledge handbook of events (pp. 347-361). Abingdon, United Kingdom: Routledge.

Sobrequés, J. (1996). La difícil construcció d’un poble. Barcelona, Spain: Lunwerg.

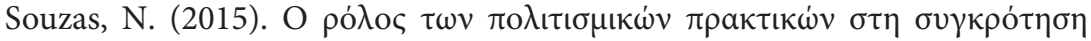

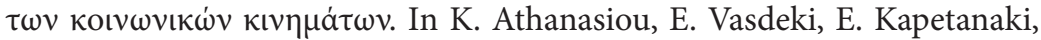
M. Karagianni, M. Kapsali, V. Makrygianni, ... \& C. Tsavdaroglou (Eds.), Urban conflicts (pp. 266-277). Thessaloniki: Ergastirio synantiseis kai sygkrouseis stin poli. Retrieved November 20, 2019, from https://www .academia.edu/12776105/Urban_Conflicts.

Spilhaus, A. (1967). The experimental city. Daedalus, 96(4), 1129-1141.

Spilsbury, J. C., Korbin, J. E. \& Coulton, C. J. (2009). Mapping children's neighborhood perceptions: Implications for child indicators. Child Indicators Research, 2, 111-131.

Spiridon, M. (2013). "The wasteland quest": Cityscapes of memory in postmodern fiction. Philologica Jassyensia, An IX, 1(17), 201-207.

Sutherland, N. (2013). Book review: Social movements and activist ethnography. Organization, 20(4), 627-635. DOI: https://doi.org/10.1177/1350 508412450219.

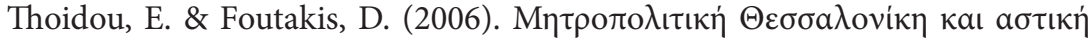

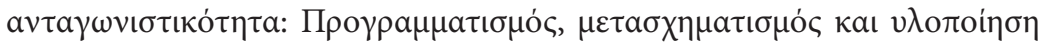

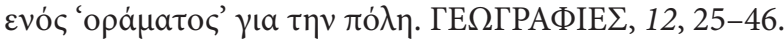

Thompson, P. (1978). The voice of the past: Oral history. Oxford, United Kingdom: Oxford University Press.

Turner, B. S. \& Rojek, C. (2001). Society and culture: Principles of scarcity and solidarity. London: SAGE Publications.

Turner, V. (1969). The ritual process: Structure and anti-structure. New York, NY: Aldine de Gruyter.

Turner, V. (Ed.). (1982). Celebration, studies in festivity and ritual. Washington, DC: Smithsonian Institution Press. 
UN (2014) World Urbanization Prospects: The 2014 Revision (Highlights). Department of Economic and Social Affairs, Population Division. New York: United Nations Available at: https://esa.un.org/unpd/wup/publications /files/wup2014-highlights.pdf.

Van Heerden, E. (2011). The social and spatial construction of two South African arts festivals as liminal events. South African Theatre Journal, 25(1), 54-71.

Voytenko, Y., McCormick, K., Evans, J. \& Schliwa, G. (2016). Urban living labs for sustainability and low carbon cities in Europe: Towards a research agenda. Journal of Cleaner Production, 123(Special Issue "Strategies for Sustainable Solutions: An Interdisciplinary and Collaborative Research Agenda”), 45-54. DOI: https://doi.org/10.1016/j.jclepro.2015.08.053.

Wagner, P. (2008). Modernity as experience and interpretation: A new sociology of modernity. Cambridge, United Kingdom: Polity Press.

Whyte, W. F. (1989). Advancing scientific knowledge through participatory action research. Sociological Forum, 4(3), 367-385.

Williams, R. J. (2004). The anxious city: British urbanism in the late twentieth century. Abingdon, United Kingdom: Routledge.

Zenk, S. N., Wilbur, J., Wang, E., McDevitt, J., Oh, A., Block, R., ... \& Savar, N. (2009). Neighborhood environment and adherence to a walking intervention in African American women. Health Education and Behavior, 36(1), 167-181. DOI: https://doi.org/10.1177/1090198108321249.

Zukin, S. (1988). Loft living: Culture and capital in urban change. London, United Kingdom: Radius.

Zukin, S. (1998). Urban lifestyles: Diversity and standardisation in spaces of consumption. Urban Studies, 35(5-6), 825-839. DOI: https://doi.org /10.1080/0042098984574.

Zukin, S. (2011). Naked city: The death and life of authentic urban places. Oxford, United Kingdom: Oxford University Press. 